\title{
CYP2E1*2 Allele
}

National Cancer Institute

\section{Source}

National Cancer Institute. CYP2E1*2 Allele. NCI Thesaurus. Code C46029.

Human CYP2E1*2 allele is located within 10q24.3-qter and is approximately $12 \mathrm{~kb}$ in length. This allele, a variant form of the CYP2E1 wild-type allele, encodes cytochrome P450 2E1*2 protein. The CYP2E1*2 allele exhibits a clinically-relevant SNP (g.1132G>A) in exon 2 that results in a $\mathrm{R} 76 \mathrm{H}$ coding change. This alteration in protein sequence severely decreases the enzymatic activity of the cytochrome P450 2E1*2 protein. 